\title{
Has the Deregulation of Deposit Interest Rates Raised Mortgage Rates?
}

\section{R. Alton Gilbert and A. Steven Holland}

L phase-out of interest rate ceilings on deposits at banks and thrift institutions by $1986 .^{1}$ This legislation was intended to increase the efficiency of financial markets, which a deregulated financial environment provides, and permit small savers to earn more competitive rates on their savings. Many of these interest rate ceilings already have been removed.

Some economists have suggested that the payment of higher interest rates to depositors has contributed to the high rates of interest in this country over the last few years. According to Arenson (1983) in the New York Times, "Economists estimate that the higher cost of bank funds probably has raised the general level of interest rates by about $1 \frac{1 / 2}{2}$ percentage points." Bacon (1983), in the Wall Street Journal, quotes Lawrence Chimerine of Chase Econometrics as estimating the same effect on long-term real rates of interest. The basic argument is that the phase-out of Regulation $Q$ has raised the interest expense of depository institutions; in response, these institutions have raised the interest rates they charge borrowers.

This article assesses the effects of the removal of deposit rate (Regulation O) ceilings on the interest rates charged on mortgage loans. While the analysis developed here applies to all interest rates, we emphasize mortgage interest rates because large proportions

R. Alton Gilbert is a Research Officer and A. Steven Holland is an economist at the Federal Reserve Bank of St. Louis. Jude L. Naes, $J$., provided research assistance.

${ }^{1}$ Depository institutions Deregulation (1980). of the deposit labilities of major mortgage lenders, such as savings and loan associations (S\&Ls) and mutual savings banks, have been subject to Regulation O ceiling rates; indeed, one reason for the removal of these ceilings was to increase the ability of these thrift institutions to attract deposits to use for mortgage lending. ${ }^{2}$ Furthermore, some analysts have suggested that such deregulation has caused mortgage mates to increase more than other long-term interest rates. ${ }^{3}$

\section{STEPS IN PHASING OUT DEPOSIT RATE CEILINGS}

Table 1 describes the steps that already have been taken in eliminating deposit interest rate ceilings. Many of these steps created new types of accounts, with ceiling rates higher than those on passbook savings accounts or with no ceilings at all. The first significant steps in the relaxation of Regulation $Q$ occurred even before the passage of the Depository Institutions

Thrifts currently hold around 40 percent of the one- to four-family residential morgage debt in the United States. They originate a much greater percentage, however, selling a large proportion of their mortgages to investors in the form of montgage passthrough certificates. See McNulty ( 1983 ) for a discussion of mortgage origination and invesiments of thrift institutions.

${ }^{3}$ For instance, Edward Friedman (1983), pp. A.40-A.41, of Chase Econometrics maintains that:

The other major effect of the new deposit structure at thrifts and banks is the permanent rise in borrowing costs for deposit institution borrowers relative to open-market rates . . . The implication is that if, for example, bond rates were to fall to much lower levels, home mortgage rates woutd not necessarily follow point for point. 
Table 1

\section{Steps in the Phase-Out of Regulation Q}

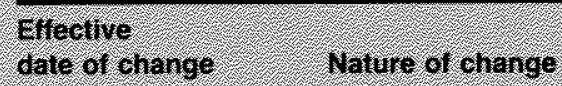

Jine 1978

Novernber 1978

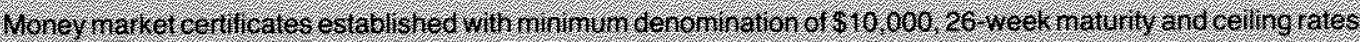
based on the 6 riverin heasuy bil tate

\section{Jine 1970}

Jine 2,1980

fine b. 1680

Jantan 1981

A

010610. 1 . 198

December 4 . 1581

$\operatorname{lax} 1.692$

Seprember 1 , 1982

Deceniber 14, 1962

Janiativ 5.1998

Aprit 1. 1988

Oetober 1 1983

Januey 1 . 1084

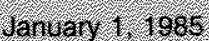

Hantar. 1.1086

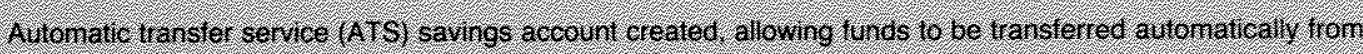
savings to diedting tecount when needed

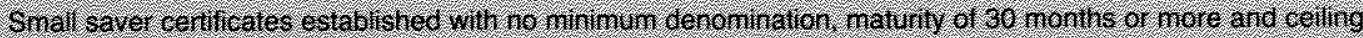

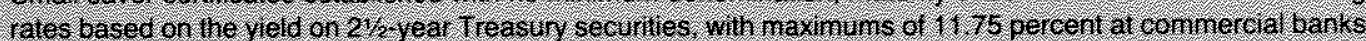
and 1200 percent in 1 inits.

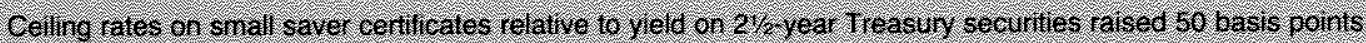
maxinuris tetained)

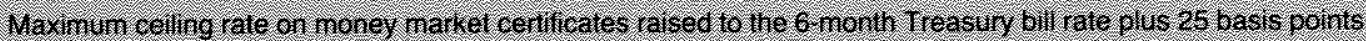

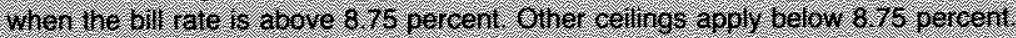

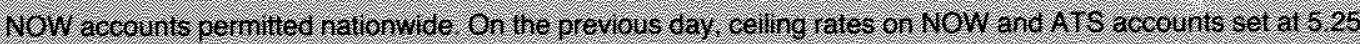
retcent

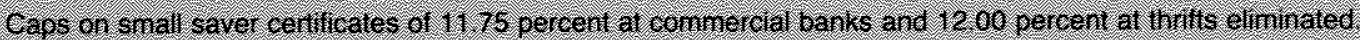

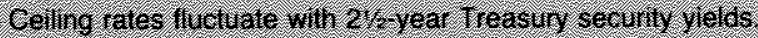

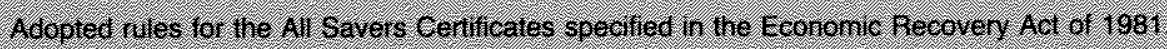

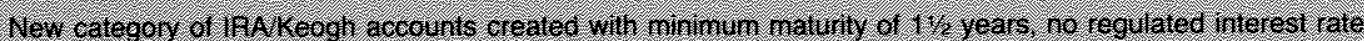

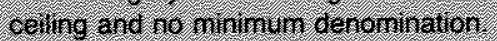

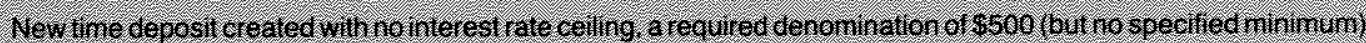

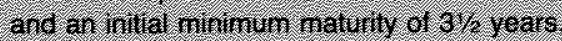

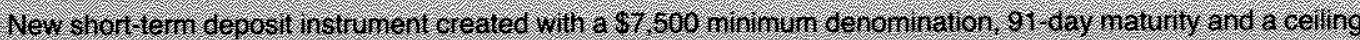

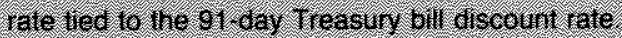

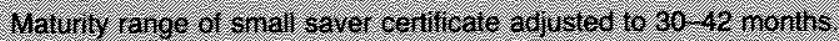

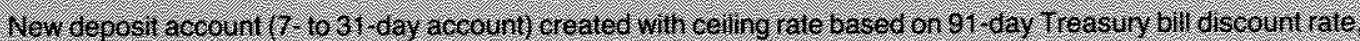

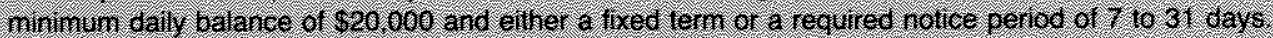

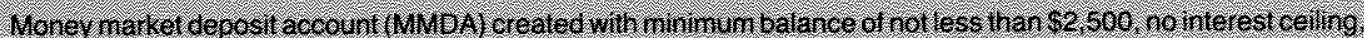

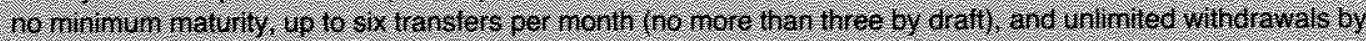
hat niessenger or in person

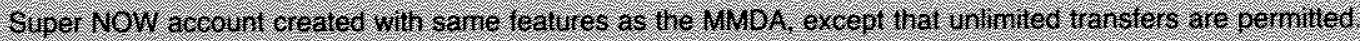

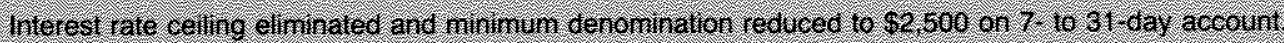

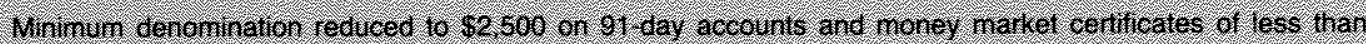
\$100000

Mininum raturivg on small saver certifcates sedtced to 16 monhs

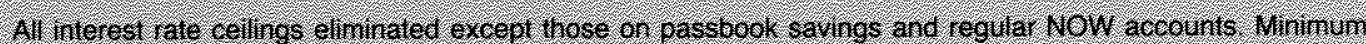

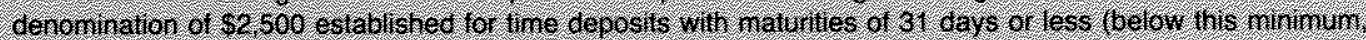
passbagk savings rates atiting

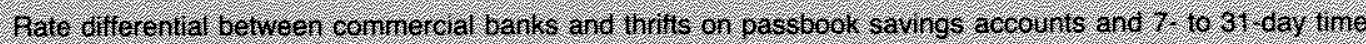

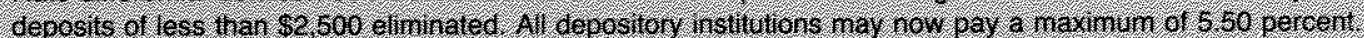

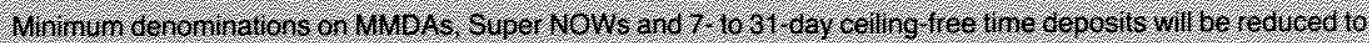
\$1000

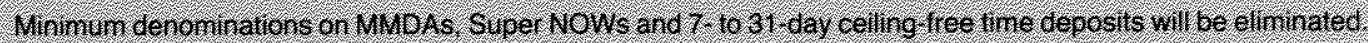


Deregulation and Monetary Control Act of 1980 (MCA), with the establishment of money maxket certificates (June 1978), automatic transfer service accounts (November 1978) and small saver certificates Gune 1979). The introduction of NOW accounts nationwide (January 1981) was the first major change in deposit interest rate ceilings put into effect under provisions of the MCA. ${ }^{4}$

The Depository Institutions Deregulation Commit* tee has the responsibility for complete removal of deposit rate ceilings by 1986 . The committee meets periodically during the transition period, and most of the changes described in table 1 represent the outcomes of these meetings. Currently, the only ceilings in effect apply to passbook savings deposits and NOW accounts. 5

\section{THE DETEPMINATION OF MORTGAGE INTEREST PATES}

In analyzing how mortgage rates are determined and how they might be affected by the deregulation of deposit interest rates, we assume that lenders, depositors and borrowers are all wealth-maximizers. In particular, we assume that lenders attempt to maximize their profits, depositors attempt to get the highest interest return they can for a given degree of risk, and borrowers search for the lowest interest rates, given other contractual characteristics of the loan.

We also make two alternative assumptions about competitive forces in the market for residential mort gages. Under the first assumption, interest rates on residential mortgages are determined in a competitive national market by the interaction of the total demand for and supply of long-term credit. Under the second assumption, each depository institution has some market power that permits it to choose the interest rate at which it lends.

In the first case, the phasing out of Regulation $O$ would increase the supply of long-term credit, due to an increase in savings by those whose returns from saving previously were limited by Regulation $Q$ ceiling rates. The increase in the supply of credit would cause long-term interest rates to fall. This is illustrated in figure 1 as a rightward movement in the supply curve from $S_{1}$ to $S_{2}$ and a reduction in the rate of interest from

${ }^{4}$ NOW accounts were avaitable for many years in New England before their introduction nationwide.

${ }^{5}$ The prohibition of interest payments on demand deposits is not affected by the MCA.

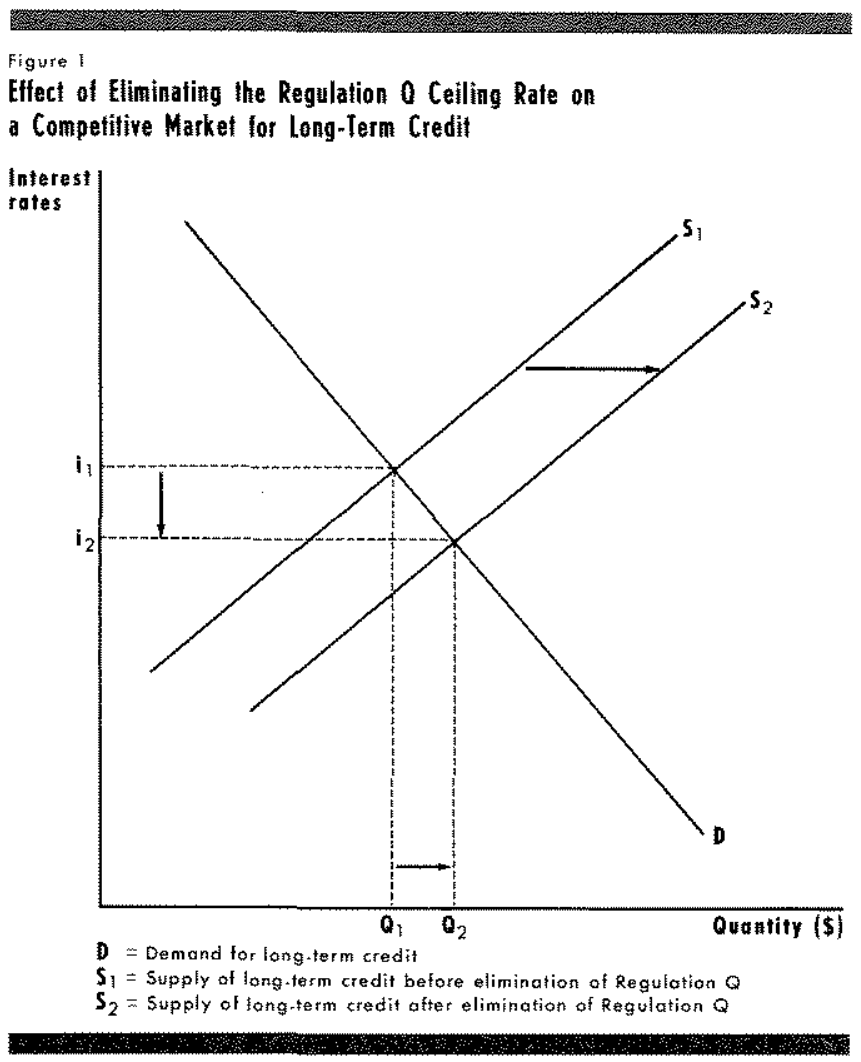

$i_{1}$ to $i_{2}$. Of course, the decline in rates may be small; it depends on the extent to which deposit rate ceilings limited the incentives for saving. There would be no change in the relationship between mortgage and other long-term interest rates, since differences in risk and liquidity that determine the spreads in interest rates between various types of long-term securities would not be affected by the phase-out of Regulation $\mathrm{Q}$.

The conclusion is not dramatically different if residential mortgages are made by specialized lending institutions that have some market power. If a fim with market power raises its mortgage rate, it will make fewer loans than if it offered mortgage oredit at lower interest rates. ${ }^{6}$ This is illustrated by the downwardsloping demand curve $\left(D_{M}\right)$ in figure 2 . We also assume that the firm must raise the interest rate it pays on small-denomination deposits if it wishes to atract more of these deposits. This is illustrated by the upward-sloping supply curve $\left(\mathrm{S}_{\mathrm{SD}}\right)$. In contrast, the firm can attract all the large-denomination deposits it wants by selling certificates of deposit at the rate of

Lenders might have such market power if most borrowers were
limited to borrowing from institutions with offices in their local area
and if the government restricted the number of institutions that may establish offices in each area. 
Figure 2

Elfect of a Regulation 0 Ceiling Rate on

the Mortgage Interest Rate Set by a Lender with Markef Power

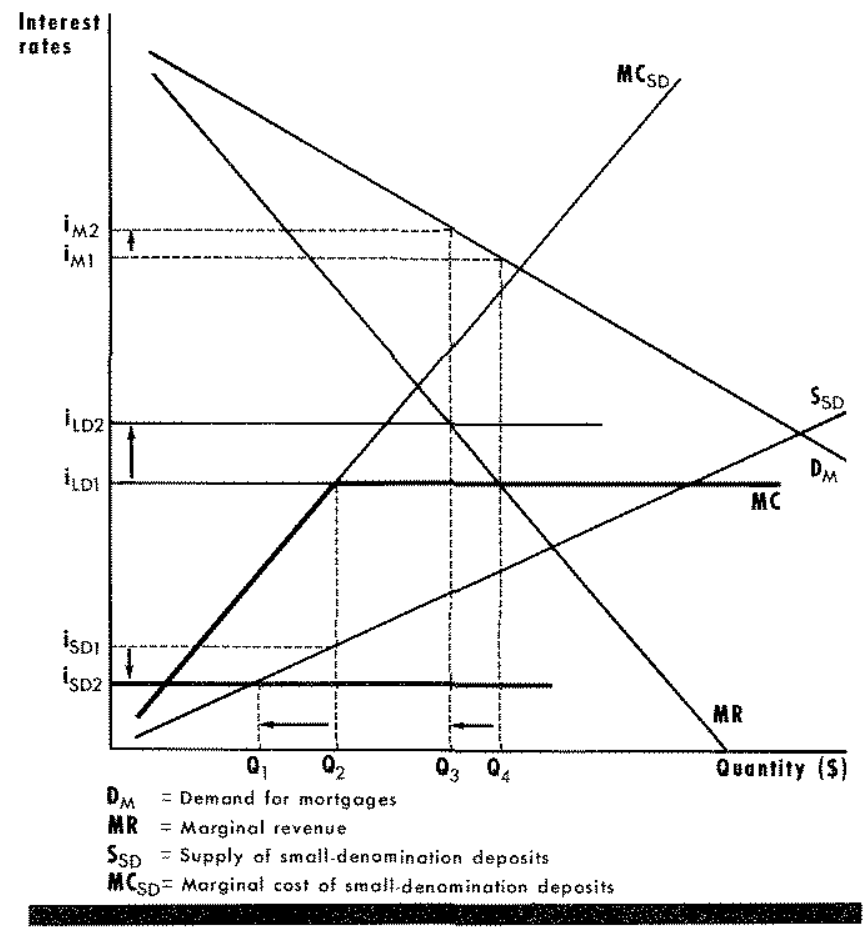

interest determined in a competitive national market. With no Regulation $Q$ ceilings in effect, we assume this interest rate is $i_{1, D}$.

The lender maximizes profits by lending the amount of mortgages at which the marginal cost the increase in total cost due to the last dollar increase in mortgage lending) equals the marginal revenue (the increase in total revenue from the last dollar increase in mortgage lending). Marginal cost and marginal revenue are illustrated by $\mathrm{MC}$ the heavy black line) and MR, respectively, in figure 2 .

The relevant marginal cost curve has two portions: (1) For deposit levels below $\mathrm{O}_{2}$, it is the marginal cost of attracting small-denomination deposits $\left(\mathrm{MC}_{\mathrm{so}}\right)$, since $\mathrm{MC}_{\mathrm{SD}}$ is less than the interest rate on large-denommation deposits, $i_{L D 1}$. (2) For deposit levels above $\mathrm{O}_{2}$, it is equal to $i_{\text {Ln }}$. If the lender wants to attract more deposits than $\mathrm{O}_{2}$ for mortgage lending, it will attract $\mathrm{Q}_{2}$ as small-denomination deposits and any additional funds as large-denomination deposits. In figure 2, if there are no ceilings on deposit rates, the profitmaximizing quantity of mortgage loans is $\mathrm{Q}_{4}$ with a mortgage rate of $i_{M 1}$ and a rate on small-denomination deposits of $i_{\mathrm{SD} 1}$.

Suppose regulators impose a maximum interest rate that may be paid on small-denomination deposits of
$\dot{\mathrm{i}}_{\mathrm{SD} 2}$, "The lender will be able to attract only $\mathrm{Q}_{1}$ of smalldenomination deposits and will have to attract any additional funds in the market for large-denomination deposits. Each lender increases its demand for largedenomination deposits, causing the interest rate on these deposits to rise (to $i_{L O 2}$, for instance). By constructing a new marginal cost curve in the same manner as before (not shown), we find that the new equilib rium mortgage rate rises to $i_{M 2}$, and the amount of mortgage lending falls to $\mathrm{Q}_{3}$.'Thus, the theory indicates that a binding ceiling on the interest rates paid on small-denomination deposits results in a higher interest rate on mortgage loans, less mortgage lending, and a higher interest rate on large-denomination deposits. ${ }^{8}$ Therefore, the elimination of Regulation $\mathbf{Q}$ ceilings should result in lower mortgage interest rates.

Given this conclusion, what are we to make of the argument that the phase-out of Regulation $\mathrm{Q}$ ceiling rates has caused mortgage interest rates to rise? It is an assertion that is inconsistent with standard economic analysis, which is based on the wealth-maximizing behavior of business fims and individuals.

\section{WHAT HAS HAPPENED TO MORTGAGE RATES?}

We now compare the recent behavior of mortgage interest rates with movements in other market rates and the average cost of funds for S\&Ls. The objective is to determine whether the evidence supports the argument that deregulation of deposit interest rate ceilings has caused mortgage interest rates to rise relative to other market interest rates of comparable duration. The mortgage interest rate series used is published by the Department of Housing and Utban Development: the average interest rate at which residential mortgage lenders make commitments to lend for long-term, fixed-rate conventional loans. The insert on pages 10 and 11 describes several series on residential mortgage interest rates and discusses the basis for choosing this measure.

\footnotetext{
${ }^{7}$ In the theoretical analysis illustrated in figure 2, Regulation $Q$ ceiling rates are assumed to apply only to small-denomination deposits. This assumption corresponds to the actual structure of ceiling interest rates under Regulation $Q$, which have exempled deposits in denominations of $\$ 100,000$ or more for many years.

${ }^{8}$ The genera conclusions would be the same if all deposits were subject to a Regula:ion $Q$ ceiling rate. Imposing a ceiling interest rate on all deposits that is below the unregulated market interest rate would reduce the amount of deposits the lender could attract. The profit-maximizing lender with market power would raise its mortgage interest rate to ration the reduced supply of mortgage credit among its customers.
} 
Chart 1

\section{Semiannual Comparison of Mortgage Interest Rate with Cost of Funds to S\&Ls and 10-Year Treasury Bond Yield}

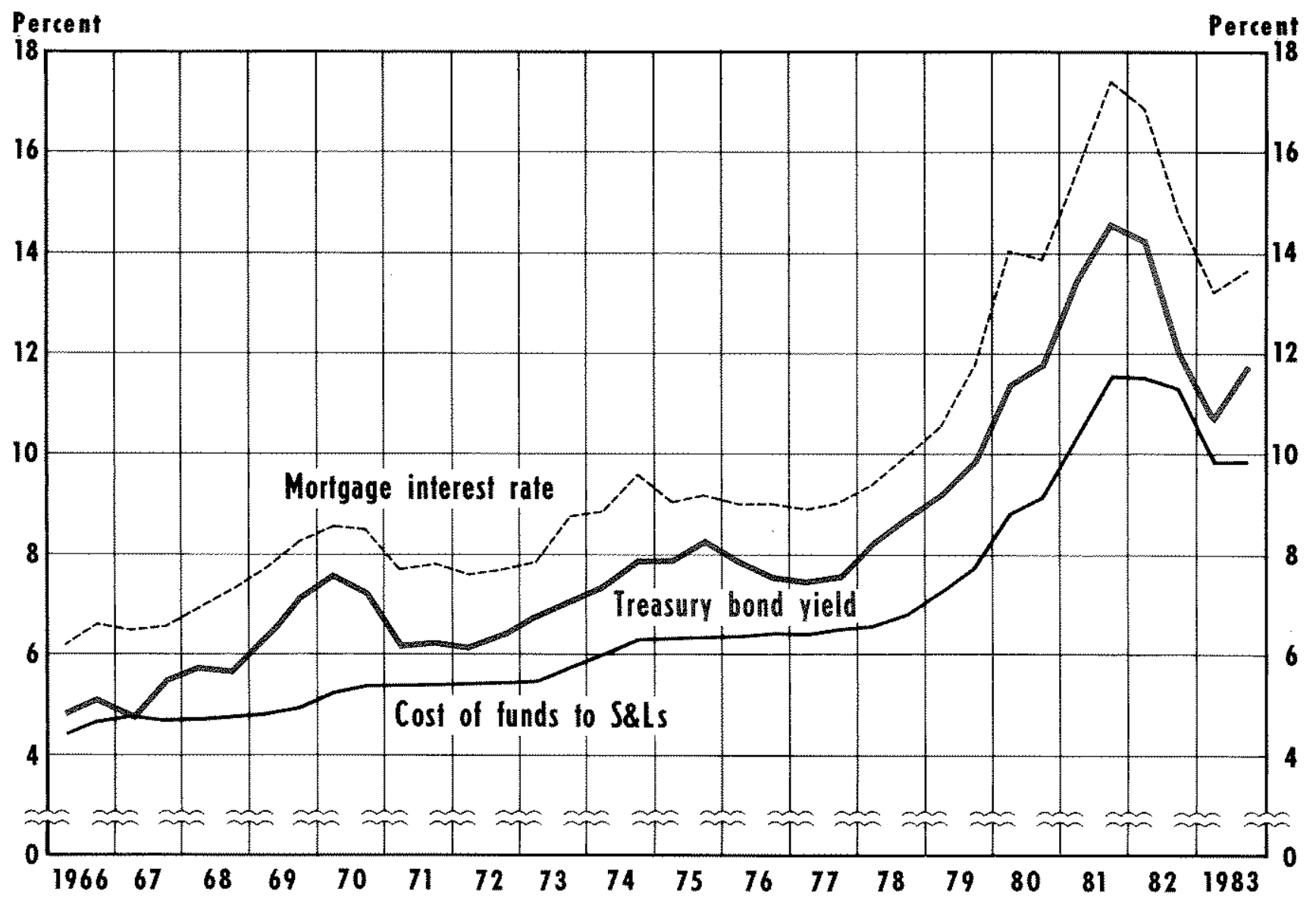

The yield on 10-vear U.S. Treasury bonds is used as a measure of the interest rate on long-tem debt obligations other than residential mortgages." The 10-year maturity approximates the average length of time that residential mortgages are outstanding. This is much shorter than the stated maturities of conventional loans because of the prepayment of a substantial number of mortgage loans before their maturity.

Chart 1 indicates that semiannual averages of the cost of funds to S\&Ls, the mortgage interest rate, and the vield on 10-year U.S. Treasury bonds tend to move together over time. ${ }^{10}$ The relationship between

${ }_{9}^{9}$ Mayer and Nathan (1983) use the 10-year Treasury bond rate for the same purpose.

${ }^{10}$ The average cost of funds for S\&Ls, obtained from the Federal Home Loan Bank Board, incorporates not only the interest S\&Ls pay changes in the mortgage and bond rates is somewhat closer (correlation coefficient of 0.897 ) than between changes in the mortgage rate and the average cost of funds (correlation coefficient of 0.816 ).

All three series were substantially higher in the late 1970s and 1980s than they had been earlier. Thus, the phase-out of Regulation $\mathrm{Q}$ ceilings allowed $S \& \mathrm{l}$ s $\mathrm{to}$ bid for funds by offering rates that kept pace with rises in market interest rates. One indicator of how rising market interest rates and the phase-out of Regulation $Q$ affected the average cost of funds for thrift institutions is the decline in the share of their deposit liabilities held in the form of passbook savings deposits. Between

on deposits, but also the interest they pay on advances from their Federal Home Loan Banks and other borrowed funds. The average cost of funds is somewhat higher than the average interest fate paid on deposits. 


\section{Four Measures of Mortgage Loan Interest Rates}

This section describes four measures of mierest fates un nontgage loans and explains why the IIIn

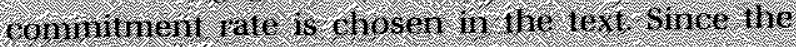
puipose of the laper is to defermine how hie phase out of Regulation Ceeling rates has affected interest rates paid b. home buyeis on new nontgage loans: Whe lise of interest ralies on mingages raded in secondary markets is muled oul. An important ort terion for inie choice or a moutgage interest rate series is that Ife trims an nom trage loans that aifect

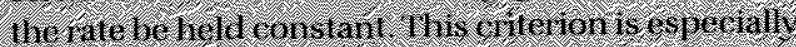
important bevause of the many changts in the terns on morteage loans in meent wears, stach as the rising share of loans with adiustable inerest tates

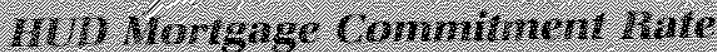

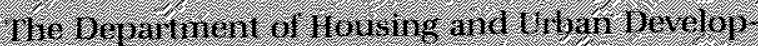
ment stifeys mator montage lenders primarily mortgage hamlen nationutde lo determine the

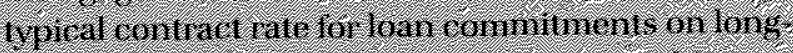

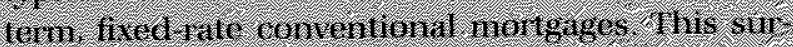

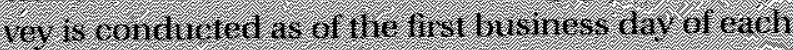

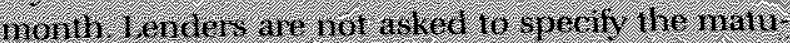

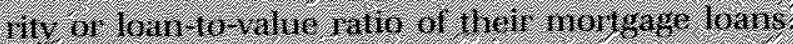
This senies does not ineorporate fees on discoim points paid by bormoner or lendes. The series starts in:Apil 1960.

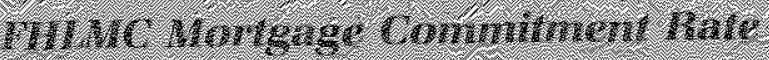

- The tederal trone Loan Nortgage Corporation

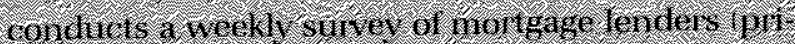
marily sid ist to determine lle contract tates for comminments on fixed rate hatts wili naturity of 30 years and ban-tow the rathe af 80 pertent this series also does nol treflent tees or dis bunt points it staris ind Amil 197 .

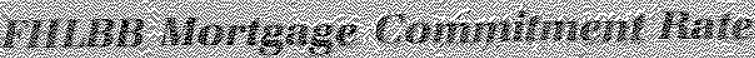

The morthage lenders neluded in the eommit: nent fate stivey of the tederal Home loan Dank Hoard in turlessis nont gate bankers, conmercial banks and mukal savings tamks the survey asks these fendtors ghoit the interest rates it which they are making eommiments to lend on newly buil homes. inder various combinations or hoan- to-klue talios The naturitu of the loras is specified as 25

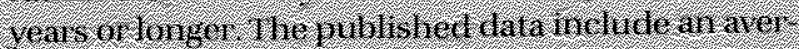
age conthict rate and an werage etfechive rate: the eflechue tate indurdes the fees and diseoum pounts amoinged over 10 years. The sertes plothed in cham 2 is for tfferme rates The comminment rate data

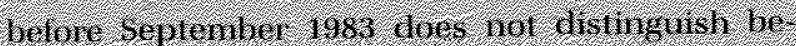
tween vates on lixed rate loans and those with adiustrille vates Theseres basced on a loan-fo-value ratio of 75 percent starts in Januay 1973.

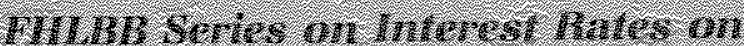

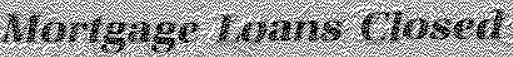

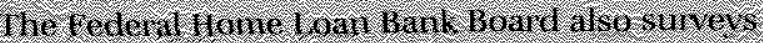
die interest hates on tesidential murgages that ate

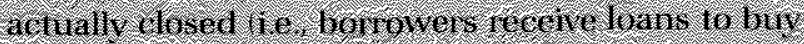
homes: This sentes is available on a consistent hasis since lanuar 1973

The dosing the senies st ilferent in several wats from the three commitment rate serres lenders denerally make conmilments for nortecte loans a ferv months befure live harns afe closed and interest rates an set ar the lime of commitment.

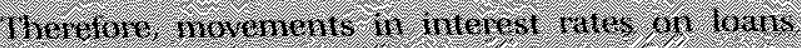
dosed tend to lag novenents in commiment rares free chat 2): Thus the tate at ime vi commitment is a betlor indicator of ihe rate at whith hom rowers dan obrain morgage eredit at a given point in ine.

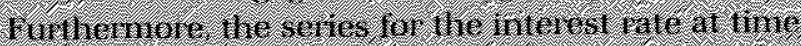
or elosing roflects a conglomeration wh han rems is imcouperatus interest jates on lixed rate adiustable ralo and griduatect pavnent loans. If also incompo

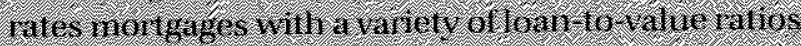
and nathines and some nortgage toans Win ths counited fates inder vinious or eatie tiranging sehomes t ror these rasions the series om loans

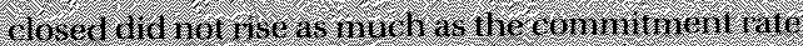
series duing $1980-52$

The lhree sertes on comminem tales tand to nove together dosid, aver limis see chant 2) The Hederal Home foan Hank boards series is slightls ingher han the onthers dining some periods the ditference feflecting primanly the inomized fers

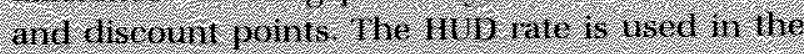
lext as the meastire of mortgage - hiterest rates sinply beranse it is avaliable over a longer period itan The other thin series. None bi hie results presented in the lext would be sulustantially aftered if a difer cht comminiment rate sentes had been used.

The ol the creative fitancing schernes hvolves tedured tate

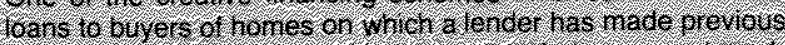

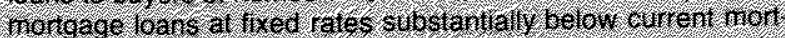

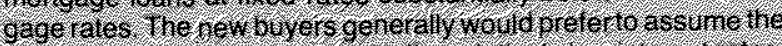

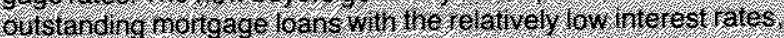

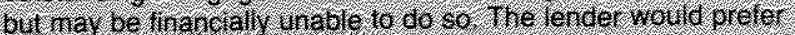

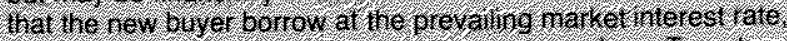

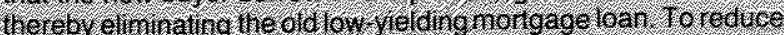

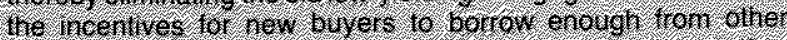

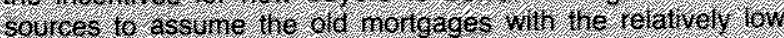

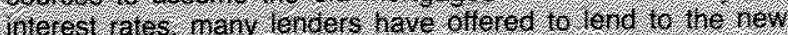

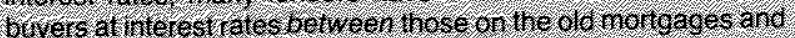

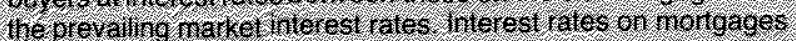

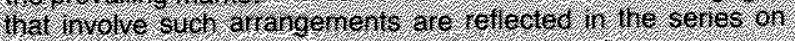
rverage interest rates on montgage ibans dosed 


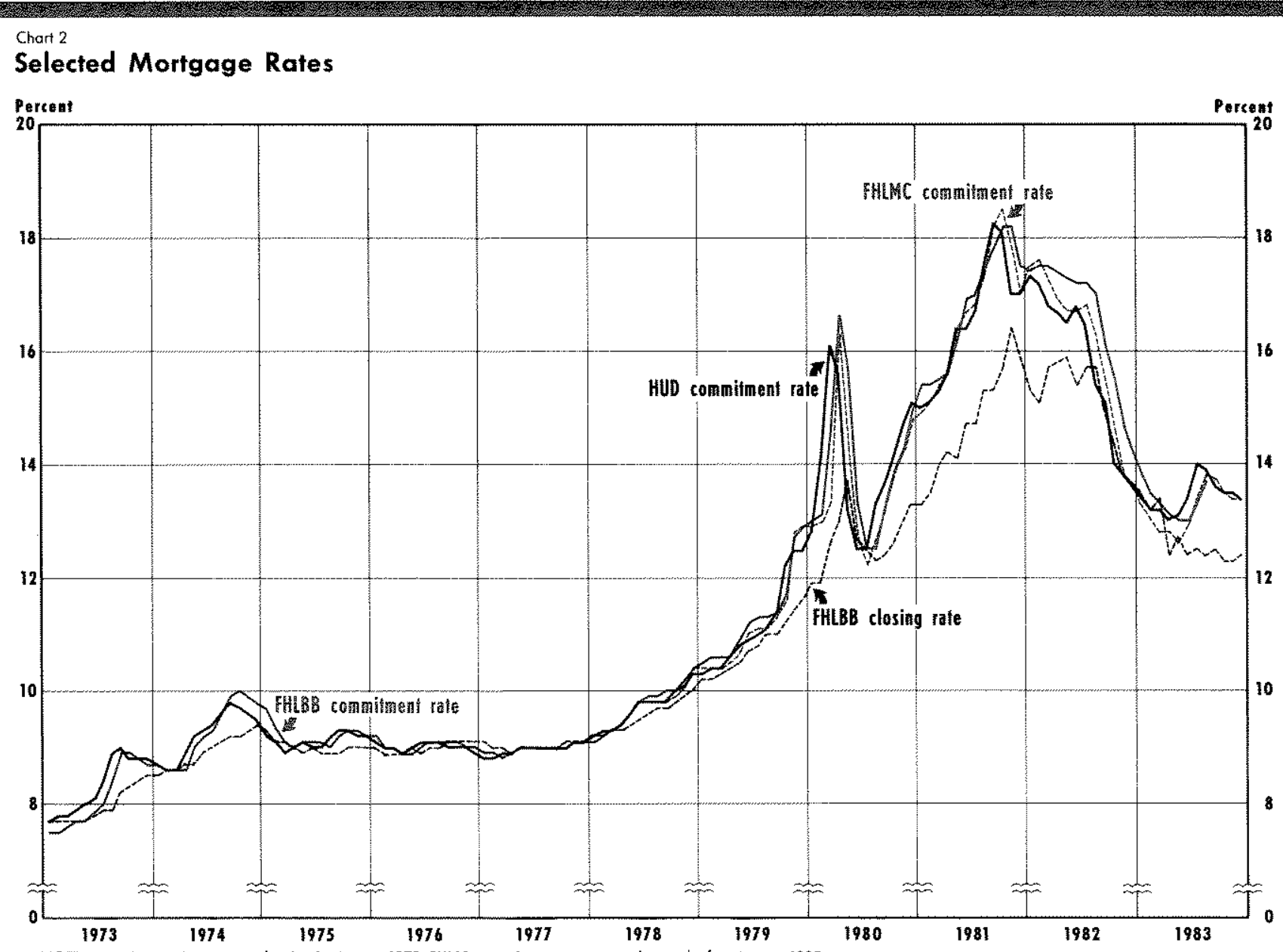

NOTE; FHLMC commitment rote begins in August 1978. FHLBß committonent rato was changed ofter August 1983

1978 and 1983, savings deposits (subject to fixed interest rate ceilings) fell from over 35 percent of total deposits to less than 15 percent. Meanwhile, the new money market certificates and money market deposit accounts each grew to represent about 17 percent of total deposits.

Chart 3 plots the same three interest rate series on a monthly basis since May 1979." The relationships among the three series enable us to see that changes in the cost of funds to S\&Ls clearly lag changes in the mortgage rate and the Treasury bond rate, usually by about two months. A simple statistical analysis confirms the visual pattern in chart 3 . The contemporaneous correlation between changes in the cost of funds and the other two series is actually negative, though not statistically significant. However, the cor-

\footnotetext{
${ }^{11}$ See Chamberlain, OIn and McKenzie (1983) for a discussion of the monthly cost of funds data. This series is actually the median cost of funds rather than the average.
}

relation between the current change in the mortgage rate and the change in the cost of funds two months later is $0.612 .^{12}$

\section{The Rise of Mortgage Rates Relative to oner Long-Tem Interest Rates}

The behavior of mortgage rates since 1980 appears to lend empirical support to the hypothesis that deregulation has resulted in higher mortgage rates relative to other long-1erm rates. The average spread between the mortgage rate and the 10-year Treasury bond rate from 1966 to 1979 ranged generally from 1 to 1.75 percentage points; in the 1980 s, it has ranged from 2 to 3 percentage points.

\footnotetext{
${ }^{12}$ The contemporaneous correlation beiween changes in the mortgage rate and changes in the yield on 10-year Treasury bonds is 0.794 , indicating that interest rates on both kinds of long-term debt instruments are affected simultaneousiy by the same credit-market influences.
} 
Chart 3

Monthly Comparison of Mortgage Interest Rate with Cost of Funds to S\&Ls and 10-Year Treasury Bond Yield

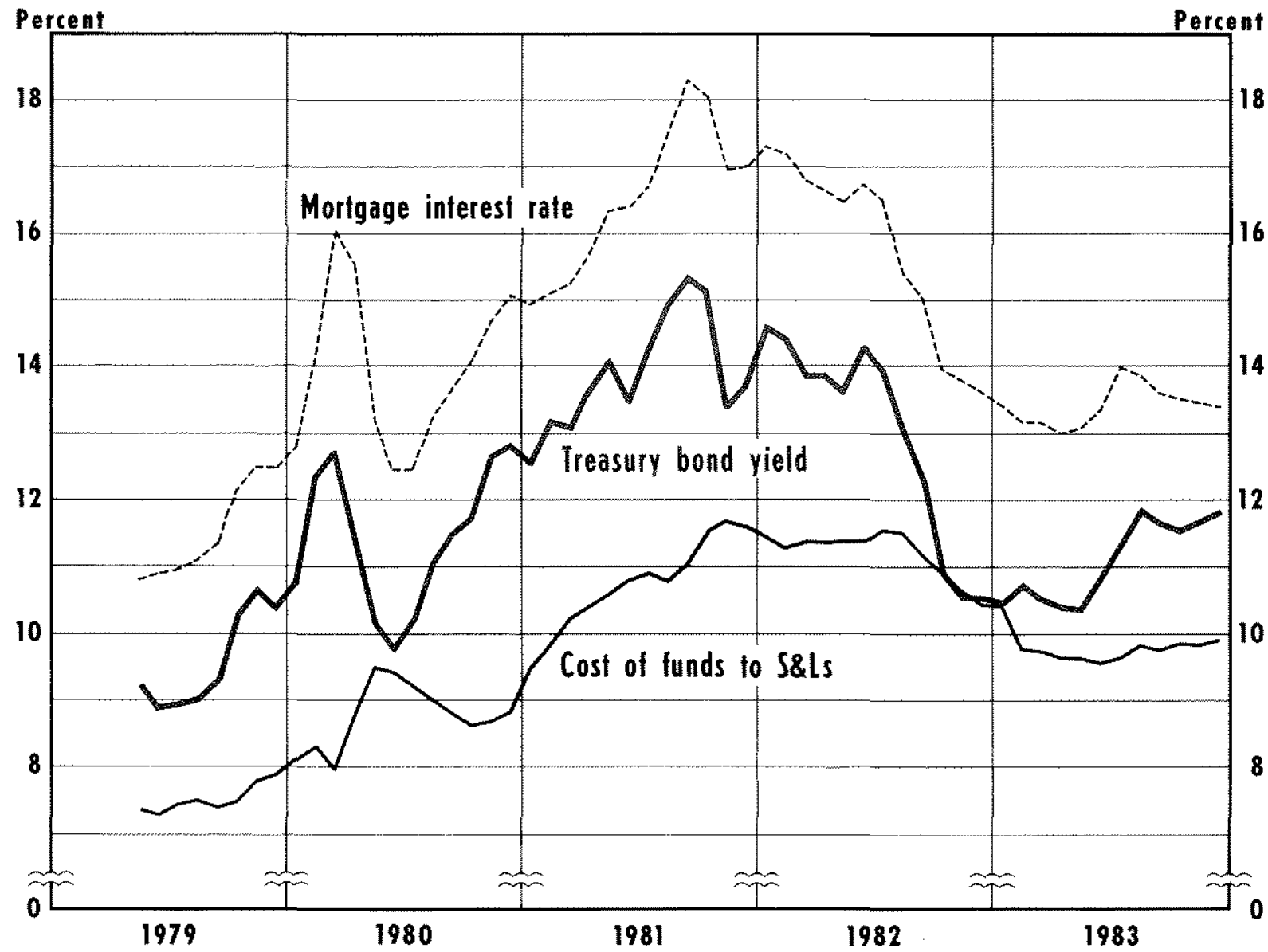

Since 1980, however, the average spread between the mortgage rate and the average cost of funds for S\&Ls also has increased, by roughly the same order of magnitude as the increase in the average spread between mortgage rates and the rate on 10-year'Treasury bonds. The gap between mortgage interest rates and the average cost of funds stayed mostly between 2 and 3.5 percentage points before 1980; since then, it has varied between 3.25 and almost 6 percentage points. Therefore, the widening in the spread between mortgage rates and the Treasury bond rate does not appear to be the result of a higher average cost of funds to S\&ls.

Why, then, did mortgage rates rise relative to rates on Treasury bonds of comparable term to maturity after 1980? The answer appeafs to involve differences between conventional residential mortgages and Treasury bonds as debt instruments. The two major differences are: (1) Most mortgages allow the borrower to pay off his debt before maturity without penalty; and (2) There is risk of default on mortgage loans. Treasury bond holders face neither prepayment risk nor default risk.

\section{Mortgage Rates and the Prepayment Option}

Investors must be compensated with higher interest rates on residential mortgages than on Treasury bonds to compensate for the risk of prepayment by debtors. ${ }^{13}$ Mortgage borrowers must pay a higher interest rate for such a "call option." The value of this option need not remain constant over time. In particular, its value will be higher during periods of more volatile long-term

\footnotetext{
${ }^{13}$ For a more thorough analysis of the role of the prepayment option in determining the spread between mortgage interest rates and Treasury bond rates, see Hendershott, Shilling and Villani (1982).
} 
interest rates than during periods of stable rates, because of the increased likelihood that the prepayment option will be exercised. Long-term interest rates were extremely variable by historical standards from 1980 to 1982. Thus, we would expect mortgage rates to rise relative to Treasury bond rates during this period.

The size of the interest rate premium necessary to compensate investors for the prepayment option on residential mortgages can be gauged by examining the spread between the yield on passthrough securities issued by the Government National Mortgage Association (GNMA) and the yield on 10year Treasury securities. The risk of prepayment is the major difference between investing in GNMA passthroughs and Treasury bonds. Investors who purchase these passthrough securities receive the interest and pincipal payments from a pool of FHA-VA governmentguaranteed residential mortgages. Thus, there is no more risk of default on the interest and principal payments on GNMA passthroughs than there is for bonds issued by the U.S. Treasury. Any prepayment of the mortgages, however, is "passed through" to the holders of the passthrough securities. ${ }^{14}$

This feature reduces the probability of a capital gain on GNMA passthrough securities compared with an investment in Treasury bonds. If long-term interest rates decline after an investor buys Treasury bonds, their market value rises, and the investor receives a capital gain if he sells them. In contrast, if long-term interest rates decline after an investor buys GNMA passthrough securities, the mortgages in the investment pool are more likely to be prepaid. Because such prepayments reduce the size of the potential capital gain, a premium in the form of a higher yield on mort gage passthroughs is required to make investors indiferent between them and Treasury bonds.

Chart 4 indicates that the spread between yields on GNMA passthrough securities and 10-year Treasury bonds rose during 1980 through early 1983. Thus, one reason for the relative increase in mortgage interest rates during those years was a rise in the rate premium necessary to compensate investors for the prepayment option on mortgages.

\footnotetext{
${ }^{14}$ Another factor that accounts for a small portion of the spread be tween rates on GNMA passthrough securities and Treasury bonds is the effect of state and local taxes. Interest earned on Treasury bonds is exempt from state and locat taxes, but earnings on mortgage passthroughs are not. There is no reason to suspect that this factor has increased in importance during recent years. There also could be differences in yields on these wo assets if investors do not view them as being of roughly equal term to maturity, as we are assuming.
}

\section{Mortgage Rates and Default Risk}

Another reason for the rise in interest rates on conventional mortgages since 1980 appears to be a general rise in interest rates on privately issued debt securities relative to yields on securities issued or guaranteed by the federal government. Table 2 shows that the average spread between interest rates on privately issued debt instruments and Treasury securities is higher in the generally recessionary period, February 1980 to November 1982, than in the expansionary period, April 1975 to January $1980{ }^{15}$ This is a reflection of the greater default risk associated with privately issued securities during recessionary periods. In each case, the differences in mean spreads between the time periods are statistically significant at the 1 percent level. ${ }^{16}$ The pattern of spreads between mortgage and Treasury bond rates is very similar to the pattem of spreads between yields on other privately issued securities and "Treasury securities of comparable duration.

Table 2 also indicates that the spreads between yields on privately issued and U.S. Treasury securities declined to neas their pre-1980 levels a few months after the economic recovery began in December 1982. The decline in the spread between the mortgage commitment rate and the Treasury bond mate occurred despite the authorization of money market deposit accounts - a major relaxation of Regulation $Q$ ceiling rates that occurred in the first month of the current recovery.

These observations are supported by the behavior of delinquency rates for mortgages. The percentage of conventional mortgages with payments delinquent for 60 days or more rose steadily from 0.61 petcent in the second quarter of 1979 to 1.37 percent in the first quarter of 1983 , then began to decline. Delinquency rates in the 1980 s have been substantially higher than in the period 1964-79, which undoubtedly accounts for a substantial portion of the higher morigage rates relative to "Treasury bond rates observed since $1980 .^{1 /}$

\footnotetext{
${ }^{15}$ The period from July 1980 to July 1981 is officially classified as an economic recovery. The financial markets, however, did not respond during that period as they fypically do during expansionary periods. Stock price indexes were little affected, and the spread between corporate Baa and Aaa bond rates (known to be influenced by cyclical factors) changed little. The lack of response is undoubtedly due to the weakness and short duration of the recovery.

${ }^{16}$ Some corporate Baa bonds grant a call option to the issuer. Part of the increase in the spread between the Baa bond rate and long-term Treasury securities, therefore, is accounted for by an increase in the value of this prepayment option.

${ }^{77}$ The average quarterly delinquency rate (60 days or more) for conventional mortgage loans between $I / 1964$ and IV/1979 was 0.58 percent; between $\mathrm{V} / 1980$ and $\mathrm{IV} / 1983$, it was 1.01 percent. This difference is statistically significant at the 1 percent level.
} 


\section{Chart 4}

\section{Selected Interest Rate Spreads}

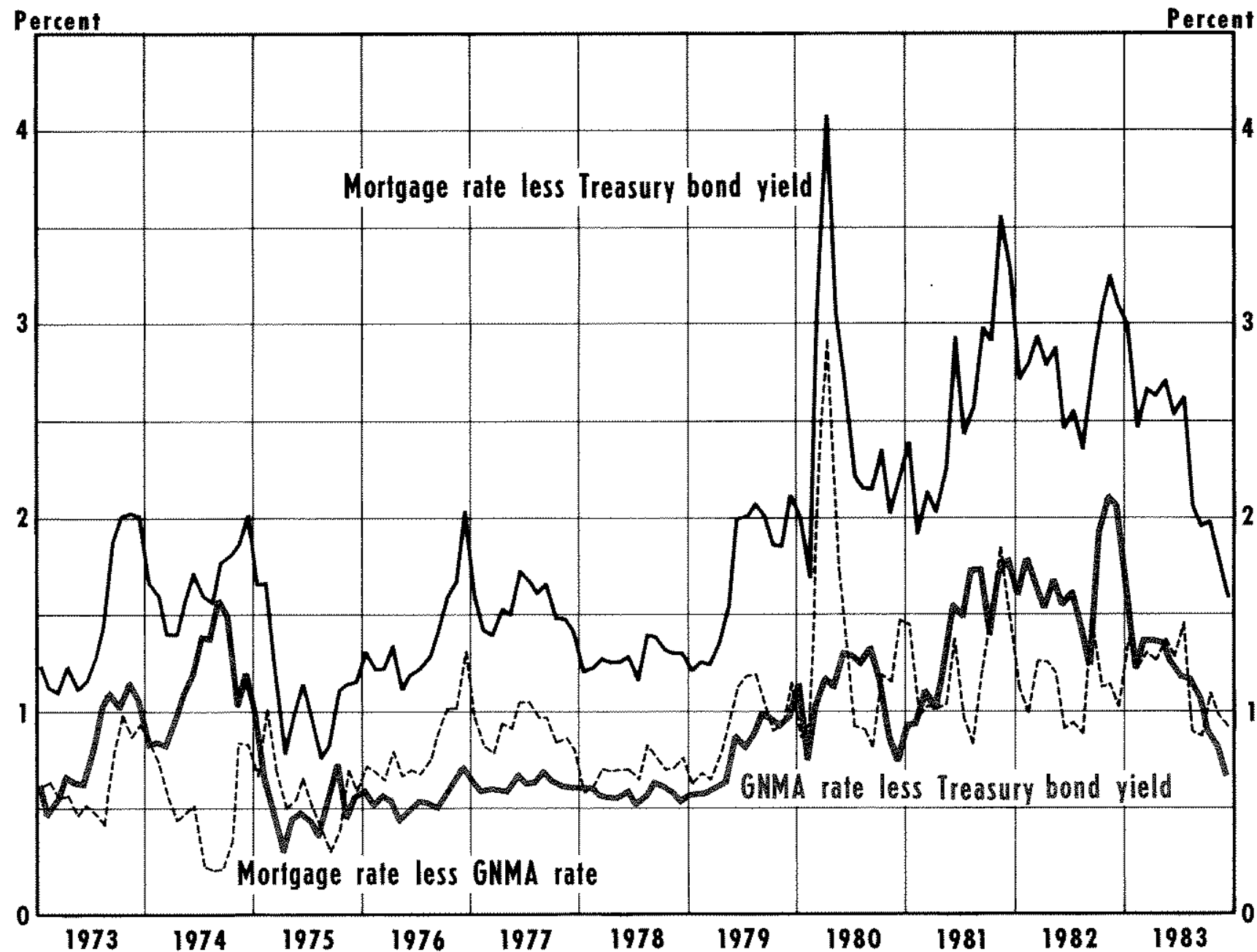

Table 2

Spreads Between Interest Rates on Privately Issured Debt Instruments and U.S. Treasury Securities (monthly average spreads in percentage points)

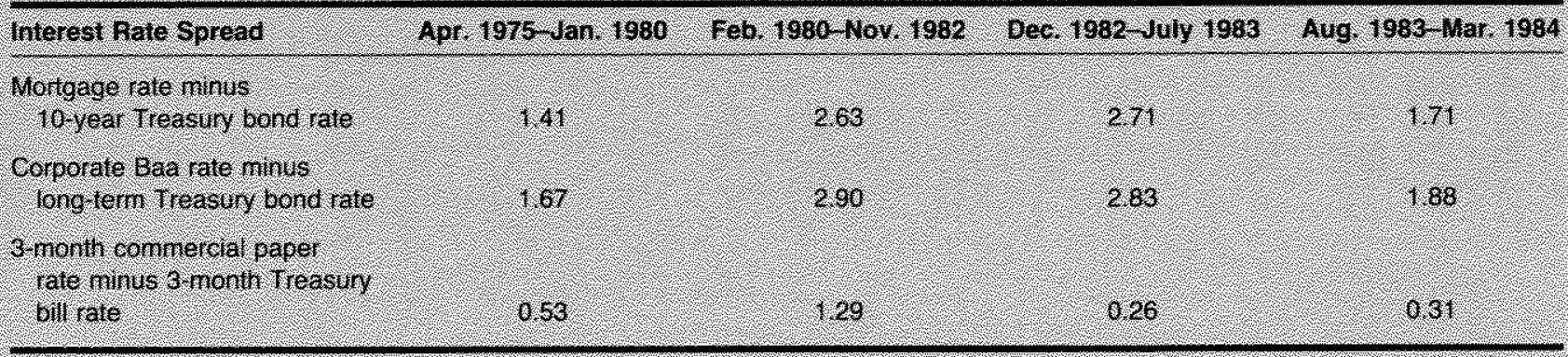




\section{Table 3}

\section{Decomposition of the Spread Between the Mortgage Rate and the 10-Year Treasury Bond Rate (monthly average spreads in percentage polnts)}

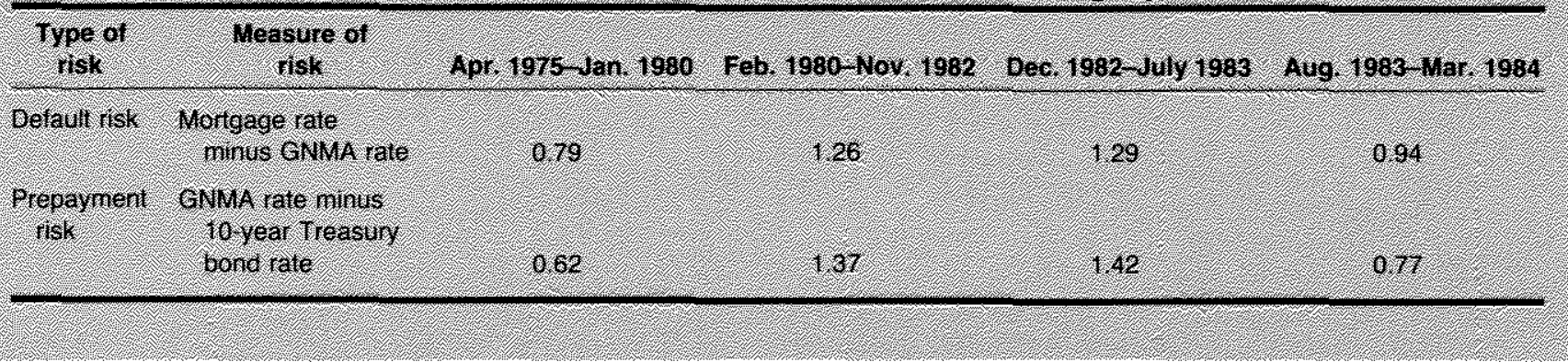

The effects of the major factors that appear to account for the rise in mortgage rates relative to Treasury bond rates can be seen in table 3 land also in chart 4). For the period $1980-82$, the premium to compensate for the risk of prepayment lapproximated by the spread between the yield on GNMA passthrough secu-

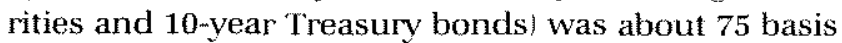
points higher on average than in $1975-79$. The default risk premium on privately issued securities not guaranteed by the government lapproximated by the spread between interest rates on new comventional residential mortgages and the yield on GNMA passthrough securities was approximately 50 basis points higher on average during this period. Therefore, both effects appear to share in the responsibility for higher mortgage interest mates relative to Treasury securities in the early 1980s. Both have declined during the current economic expansion.

\section{CONCLUSION}

Economic theory suggests that the deregulation of deposit interest rates does not cause mortgage rates to rise and may, in fact, result in lower mortgage interest rates than would otherwise be observed. Nonetheless, many believe that the higher average cost of obtaining loanable funds that results from deregulated deposit rates have led to higher mortgage rates.

Since the introduction of new types of deposits with flexible interest ceilings (or no cellings at all), the averm age interest rate on mortgage loans, the average cost of funds for savings and loan associations, and market interest rates in general have risen substantially. The notion that higher mortgage rates are due to the removal of deposit interest rate ceilings, however, is not supported.
Although mortgage rates have moved higher relative to government bond rates of similar duration following the beginning of deregulation, that pattern appears to be unrelated to the deregulation of deposit rates. Instead, it was the result of more variable interest rates, which caused a higher premium for the option of prepaying a mortgage loan, and the economic downturn in the early 1980s, which raised the premium for the risk of default on mortgages. Since inferest rates have become less variable and an economic expansion has begun, the spreads between motgage rates and govm ermment bond rates have fallen over the last year to close to their pre-1980 level.

\section{REFERENGES}

Arenson, Karen W. "Why High Interest Rates Are Here to Stay," New York Times, October 9, 1983.

Bacon, Kenneth H. "Flexible Interest Rates May Add to Stabitity," Wall Street Joumal, November 7, 1983.

Chamberlain, Charlotte A., Virginia K. Olin and Joseph A. McKen. zie. "Monthly Cost of Funds," Federal Home Loan Bank Board Journal (January 1983), pp. 34-37.

Depository Institutions Deregulation and Monetary Control Act of 1980. S. Rept. No. 96-640, 96 Cong. 2 Sess. (GPO, 1980), title II sec. 202(a).

Friedman, Edward A. "Key Consumer Markets of the 1980s: Autos, Energy, Finance and Health Care," in Long-Term Special Report: Consumer Markets in the 1980s (Chase Econometrics, July 1983), pp. A.29-A.46.

Hendershott Patric H., James D. Shilling and Kevin E. Villani. "The Determination of Home Mortgage Rates: Empirical Results for the 1975-81 Period" 'paper presented al a joint session of the meetings of the American Finance Association and the American Rea Estate and Urban Economics Association, New York, December 29, 1982)

Mayer, Thomas, and Harold Nathan. "Mortgage Rates and Regula-

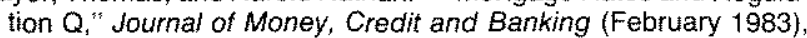
pp. $107-15$.

MoNulty, James E. "Secondary Mortgage Markets: Recent Trends and Research Results." Federal Home Loan Bank of Atlanta Re. view (December 1983), pp. $\$-5$. 